\title{
INTERFERENSI POLA KALIMAT BAHASA INDONESIA TERHADAP KETERAMPILAN BERBICARA BAHASA JERMAN SISWA
}

\author{
Rahmayana $^{1}$, Mantasiah $\mathbf{R}^{2}$, Muddin ${ }^{3}$, Hasmawati ${ }^{4}$ \\ Fakultas Bahasa dan Sastra,Universitas Negeri Makassar \\ Email : rahmayanaalimuddin@gmail.com ${ }^{1}$
}

\begin{abstract}
ABSTRAK
Tujuan penelitian ini adalah untuk mengetahui bagaimana penggunaan pola kalimat bahasa Indonesia terhadap keterampilan berbicara bahasa Jerman siswa kelas XI SMA Negeri 2 Bantaeng. Penelitian ini adalah penelitian deskriptif kualitatif. Populasi penelitian ini adalah seluruh siswa kelas XI SMA Negeri 2 Bantaeng. Sampel dalam penelitian ini adalah siswa kelas XI IPA 2 yang berjumlah 32 siswa. Data yang diperoleh dianalisis dengan menggunakan teknik persentase. Hasil analisis data menunjukan bahwa interferensi penggunaan pola kalimat bahasa Indonesia terhadap keterampilan berbicara bahasa Jerman siswa kelas XI SMA Negeri 2 Bantaeng adalah 11,4\%.
\end{abstract}

\section{Kata Kunci: Interferensi, Keterampilan Berbicara, Bahasa Jerman, Bahasa Indonesia}

\begin{abstract}
The purpose of this study was to find out how to use Indonesian sentence patterns on German speaking skills in class XI students of SMA 2 Bantaeng. This research is a qualitative descriptive study. The population of this study were all students of class XI SMA 2 Bantaeng. The sample in the study amounted to 32 students. The data obtained were analyzed using percentage techniques. The results of the data analysis showed that the interference with the use of Indonesian sentence patterns on students' German speaking skills was $11.4 \%$.
\end{abstract}

\section{Keywords: Interference, Speaking Skill, German Language, Indonesian Language}

\section{PENDAHULUAN}

Bahasa Jerman merupakan salah satu bahasa asing yang cukup prospektif untuk dipelajari. Bahasa Jerman digunakan oleh cukup banyak penutur bahasa di dunia. Selain itu, banyak istilah-istilah dalam bahasa Jerman yang digunakan dalam bidang-bidang tertentu, seperti kedokteran, hukum, atau di bidang teknologi. Bahasa Jerman telah diajarkan di Indonesia sejak tahun 80-an pada sekolah SMA/SMK/MAN sebagai salah satu bahasa asing selain bahasa Inggris.

Pembelajaran bahasa Jerman mencakup empat kompetensi dasar yang saling terkait, yaitu kemampuan menyimak (Hören), keterampilan berbicara (Sprechen), kemampuan membaca (Lesen), dan keterampilan menulis (Schreiben). Selain itu, aspek kebahasaan lain seperti gramatika dan kosakata diajarkan secara terpadu guna menunjang penguasaan keempat kompetensi tersebut.

Berdasarkan kurikulum Terpadu Satuan Pendidikan (KTSP) tahun 2006 dikembangkan empat kompetensi berbahasa, yaitu mendengar, berbicara, membaca, dan menulis. Keempat kompetensi berbahasa tersebut dikembang secara terintegrasi dengan didukung penguasaan struktur dan kosakata bahasa Jerman. Secara teoretis 
pengajaran yang terintegrasi ini sejalan dengan pendekatan komunikatif yang selama ini digunakan sebagai landasan. Berdasarkan pendekatan ini, tujuan yang hendak dicapai adalah peserta didik diharapkan mampu berkomunikasi baik secara lisan maupun tulisan dalam bahasa Jerman. Tujuan yang harus dicapaii oleh peserta didik kelas XI yaitu: agar peserta didik dapat: (1) mengungkapkan informasi secara lisan tentang identitas diri dengan lafal tepat dengan kalimat sederhana sesuai konteks yang mencerminkan kecakapan berbahasa dengan baik; (2) melakukan dialog sederhana tentang identitas diri dengan lancar, yang mencerminkan kecakapan berkomunikasi dengan baik.

Terdapat beberapa aspek yang harus diperhatikan oleh pendidik dalam meningkatkan kualitas proses pembelajaran bahasa Jerman bagi penutur bahasa Indonesia seperti model pembelajaran yang digunakan (Yusri et all, 2018; Romadloni et all, 2017; Qalbi et all, 2017; Harianto et all, 2017; Mantasiah et all, 2017;2018), ataupun media pembelajaran yang digunakan (Zulfikar et all, 2017; Tenri, 2017).

Salah satu permasalahan yang dialami oleh pembelajat bahasa Jerman adalah terkait interferensi (Yusri, 2017). Pembelajar bahasa asing kerap kali tidak menyadari adanya penggunaan unsur-unsur bahasa yang lain yang digunakan dalam berkomunikasi atau dalam istilah linguistik disebut interferensi. Interferensi terjadi karena penutur bilingual yaitu penutur yang menguasai dua bahasa. Interferensi terjadi baik dalam pengucapan maupun penulisan. Dalam pengucapan biasanya interferensi terjadi pada pelafalan atau ujaran-ujaran. Biasanya pembelajar bahasa asing dipengaruhi pola-pola kalimat bahasa pertama atau bahasa nasionalnya ke dalam bahasa sasaran. Dengan kata lain ada persentuhan antara bahasa pertama (B1) dengan bahasa sasaran (B2). Hal tersebut disebabkan adanya kontak bahasa daerah dan atau bahasa nasional dengan bahasa asing, sehingga terjadi fenomena saling mempengaruhi, pengaruh inilah yang disebut interferensi.

Permasalahan ini diperkuat oleh hasil observasi yang telah dilakukan di SMA Negeri 2 Bantaeng yang menunjukkan bahwa kebanyakan peserta didik mengalami permasalahan ketika berbicara dalam bahasa Jerman. Hal itu disebabkan oleh: (1) peserta didik merasa takut mengungkapkan ide saat berbicara dengan menggunakan bahasa Jerman, karena mereka belum menguasai struktur dan kosakata bahasa Jerman; (2) peserta didik kurang percaya diri terhadap kemampuan yang dimilikinya, sehingga ketika berbicara mereka terlihat gugup, malu dan takut bila melakukan kesalahan. Hal tersebut merupakan penyebab rendahnya keterampilan berbicara bahasa Jerman di SMA Negeri 2 Bantaeng. Berdasarkan latar belakang di atas, maka fokus masalah dalam penelitian ialah bagaimana penggunaan pola kalimat bahasa Indonesia terhadap keterampilan berbicara siswa kelas XI SMA Negeri 2 Bantaeng.

\section{INTERFERENSI}

Peristiwa interferensi dalam menggunakan unsur-unsur bahasa lain dalam suatu bahasa yang dianggap sebagai suatu kesalahan karena menyimpang dari kaidah atau aturan bahasa yang digunakan. Ada beberapa pendapat mengenai defenisi interferensi diantaranya: Achmad dan Abdullah, (2012:180) mengatakan bahwa interferensi merupakan salah satu akibat dari kontak bahasa sehingga menimbulkan pengaruh terhadap bahasa lain. Senada dengan Achmad dan Abdullah, Mahmudah (2012: 83) menyatakan bahwa interferensi merupakan gejala umum dalam sosiolinguistik yang terjadi sebagai akibat dari kontak bahasa, yaitu penggunaan dua bahasa atau lebih dalam masyarakat tutur yang multilingual. Berdasarkan kedua pendapat ahli di atas dapat disimpulkan bahwa interferensi adalah akibat dari kontak bahasa, yaitu penggunaan dari dua bahasa atau lebih dalam masyarakat tutur. 
Interferensi dianggap sebagai gejala yang sering terjadi dalam penggunaan bahasa. Interferensi dapat terjadi pada saat penutur menggunakan pola bahasa pertama (B1) ketika sedang berbicara dalam bahasa sasaran (B2). Adapun faktor-faktor yang melatarbelakangi terjadinya interferensi dikemukakan oleh beberapa ahli antara lain sebagai berikut: Menurut Lubis (2012: 6) ada empat faktor yang menyebabkan terjadinya interferensi, yaitu; (1) kekacauan pilihan bahasa; (2) latar belakang daerah siswa; (3) keterampilan menggunakan bahasa, dan (4) kerancuan bahasa guru. Interferensi yang timbul karena kebutuhan kosakata baru, cenderung dilakukan secara sengaja oleh pemakai bahasa. Persentuhan dua bahasa, kelalaian kedwibahasawan, kurangnya penguasaan terhadap suatu bahasa, kepentingan gaya/kepuitisan berbahasa. Lebih lanjut Purwo (2000: 235) menyatakan bahwa ada tiga penyebab terjadinya interferensi, yaitu; (1) tidak baiknya penguasa bahasa di wilayah tersebut; (2) adanya niat menambah gengsi; dan (3) adanya kepentingan bisnis. Berdasarkan kedua pendapat ahli di atas dapat disimpulkan bahwa faktor-faktor yang memengaruhi terjadinya interferensi adalah karena ketidakmampuan seorang penutur mengolah dan memahami sistem suatu bahasa yang sedang dipelajari.

\section{METODE PENELITIAN}

Variabel penelitian ini adalah variabel tunggal yaitu interferensi penggunaan pola kalimat bahasa Indonesia terhadap keterampilan berbicara bahasa Jerman siswa kelas XI SMA Negeri 2 Bantaeng. Desain Penelitian ini adalah penelitian deskriptif yang secara khusus ditujukan untuk mengetahui bagaimana gambaran objek penelitian secara deskriptif (Jufri, 2017;2007). Populasi dalam penelitian ini adalah seluruh siswa kelas XI yang belajar bahasa Jerman di SMA Negeri 2 Bantaeng yang dengan jumlah 323 siswa. Sampel penelitian ini adalah siswa kelas XI SMA
Negeri 2 Bantaeng. Penarikan sampel dalam penelitian ini dilakukan dengan teknik Random Sampling. Pengumpulan data dalam penelitian ini dilakukan dengan cara memberikan tes wawancara kepada siswa berupa memberikan beberapa pertanyaan kepada siswa tentang Traumberuf, kemudian siswa menjawab pertanyaan yang diberikan. Data yang diperoleh akan dianalisis menggunakan teknik persentase.

\section{HASIL DAN PEMBAHASAN}

Hasil penelitian menunjukkan bahwa interferensi penggunaan pola kalimat bahasa Indonesia dalam keterampilan berbicara bahasa Jerman yang dilakukan oleh siswa adalah penggunaan kata kerja modal (Modalverben) pada anak kalimat, penggunaan kata keterangan (waktu), penempatan kata kerja utama pada anak kalimat (kalimat subordinatif), penggunaan kata depan (Präposition), dan penggunaan kata kerja utama dalam kalimat. Interferensi yang paling banyak dilakukan oleh siswa adalah interferensi pada penempatan kata kerja modal (Modalverben) pada anak kalimat, karena siswa cenderung menggunakan pola kalimat bahasa Indonesia sebagai bahasa pertama (B1), jadi dalam penyusunan kalimat bahasa jerman sebagai bahasa kedua (B2) siswa masih banyak menggunakan pola kalimat bahasa Indonesia. Persentase interferensi keseluruhan aspek tersebut adalah $11,4 \%$.

Beberapa hal yang mengakibatkan terjadinya interferensi pola kalimat pada saat siswa berbicara dalam bahasa Jerman, yaitu: siswa kesulitan dalam berbicara bahasa Jerman karena kekurangan kosakata dan sulit menemukan padanan kata yang sesuai. Selain itu, penggunaan bahasa Indonesia yang intens membuat siswa cenderung menggunakan pola bahasa Indonesia (B1) pada saat berbicara dalam bahasa Jerman (B2). Sehingga tanpa sadar siswa telah melakukan kontak bahasa yakni dari bahasa Indonesia ke bahasa Jerman. Hal yang lebih dominan mengakibatkan terjadinya 
interferensi adalah penerapan unsur bahasa Indonesia (B1) ke dalam bahasa Jerman (B2).

Hal ini dapat diketahui dari banyaknya siswa yang melakukan kesalahan konjugasi dalam penyusunan kalimat bahasa Jerman pada saat berbicara. Seperti yang diketahui bahwa dalam bahasa Indonesia tidak mengenal istilah konjugasi, sehingga dalam menyusun kalimat bahasa Jerman, siswa cenderung melakukan kesalahan pada aspek konjugasi. Selain konjugasi, pola penyusunan kata kerja modal (Modalverben) dalam bahasa Indonesia dan bahasa Jerman berbeda. Dalam bahasa Jerman, penyusunan pola kalimat menggunakan kata kerja modal (Modalverben) yakni kata kerja infinitiv harus berada diakhir kalimat apabila terdapat kata kerja modal (Modalverben), sehingga pada saat siswa menyusun kalimat menggunakan kata kerja modal cenderung menggunakan pola kalimat bahasa Indonesia.

\section{KESIMPULAN}

Berdasarkan hasil analisis data yang telah diuraikan maka dapat disimpulkan bahwa interferensi penggunaan pola kalimat bahasa Indonesia terhadap keterampilan berbicara bahasa Jerman siswa kelas XI SMA Negeri 2 Bantaeng sering dilakukan siswa dalam berbicara bahasa Jerman. Siswa sudah mampu berbahasa Jerman, tetapi masih cenderung menggunakan pola kalimat bahasa Indonesia sebagai bahasa pertama (B1) tanpa memperhatikan pola kalimat bahasa Jerman (B2) yang baik dan benar.

\section{DAFTAR PUSTAKA}

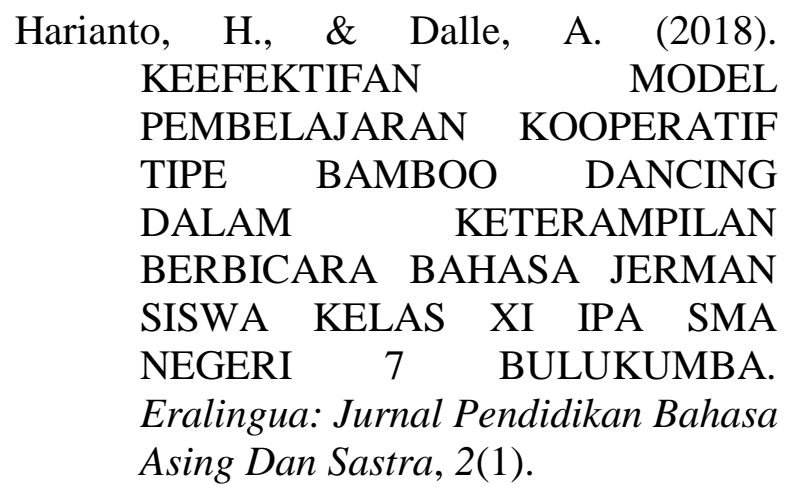

HP, Achmad Dan Abdullah, Alek. (2012). Linguistik Umum. Erlangga

Iskandarwassid Dan Sunendar, D. (2013). Strategi Pembelajaran Bahasa. Bandung: Penerbit NUANSA.

JUFRI, J. (2007). Metode Penelitian Bahasa, Sastra Dan Budaya.

Jufri, J. (2007). Metode Penelitian Bahasa. Sastra Dan Budaya.

JUFRI, J. (2017). Strategi Pembelajaran Bahasa.

Lubis, Fitriani. (2012). Penyebab Interferensi Gramatis Bahasa Batak Angkola Dalam Karangan Berbahasa Indonesia Siswa Kelas 5 SDN 105010 Sigama Kecamatan Padang Bolak Taparuli Selatan. Medan: Universitas Negeri Medan, Diambil Dari Http://Digilib.Unimed.Ac.Id/Public/U NIMED-Article-23372-

Fitriani\%20lubis.Pdf, Diakses Pada Tanggal 28 Januari 2018.

Mahmudah. (2012). Sosiolinguistik. Makassar: Universitas Negeri Makassar.

Mantasiah, R. (2018, June). Pay It Forward Model In Foreign Language Learning To Increase Student's Self Efficacy And Academic Motivation. In Journal Of Physics: Conference Series (Vol. 1028, No. 1, P. 012178). IOP Publishing.

Mantasiah, R., Juffri, J., \& Yusri, Y. (2017). Keefektifan Model Pembelajaran Jaring Laba-Laba (Webbed) Dalam Keterampilan Menulis Karangan Sederhana Bahasa Jerman. Indonesian Journal of Educational Studies, 20(2).

Nurjamal, Daeng Dkk. (2015). Terampil Berbahasa, Bandung: CV. Alfabeta.

Purwo, Bambang Kaswanti. (2000). Kajian Serba Linguistik. Jakarta: Gunung Mulia, Diambil Dari Http://Www.Books.Google.Co.Id, Diakses Pada Tanggal 25 Januari 2018. 
Qalbi, U. N., Mantasiah, R., Jufri, J., \& Yusri, Y. (2017). Efektivitas Model Pembelajaran Kooperatif Tipe Teams Games Tournaments Dalam Keterampilan Menulis Bahasa Jerman Siswa Kelas XII IPA SMA Negeri 1 Bontonompo Kabupaten Gowa. Indonesian Journal of Educational Studies, 20(1).

Romadloni, A., \& Mantasiah, R. Intercultural Approach In Foreign Language Learning To Improve Students' Motivation. Senior Editors, 61.

Saleh, Muhammad Dan Mahmudah. (2006) . Sosiolinguistik. Makassar: Badan Penerbit Universitas Negeri Makassar.

Tenri, A., Asri, W. K., \& Azizah, L. (2017). KEEFEKTIFAN PENGGUNAAN MEDIA BRETTSPIEL DALAM KETERAMPILAN BERBICARA BAHASA JERMAN SISWA KELAS $X$ SMA NEGERI 11 MAKASSAR. Eralingua: Jurnal Pendidikan Bahasa Asing Dan Sastra, 1(1).
Yusri, Y. (2016). Kesalahan Pembentukan Komposita Nomina Dalam Bahasa Jerman Oleh Mahasiswa Program Studi Pendidikan Bahasa Jerman Fakultas Bahasa Dan Sastra Universitas Negeri Makassar. Jurnal Nalar Pendidikan, 4(1).

Yusri, Y., Mantasiah, R., \& Jufri, J. (2018). The Use Of Two Stay Two Stray Model In English Teaching To Increase Student's Learning Outcome. Journal of Advanced English Studies, 1(1), 39-43.

Zulfikar, Z., \& Azizah, L. (2017). KEEFEKTIFAN PENGGUNAAN MEDIA PEMBELAJARAN KARTU KUARTET DALAM PEMBELAJARAN KETERAMPILAN BERBICARA BAHASA JERMAN SISWA KELAS XI MA NEGERI 1 MAKASSAR. Eralingua: Jurnal Pendidikan Bahasa Asing Dan Sastra, 1(2). 